\title{
"Municipal Affairs" in the California Constitution
}

\begin{abstract}
HIEF Justice Morrison, in 1880, said; "It is manifestly the intention of the constitution to emancipate municipal governments from the authority and control formerly exercised over them by the legislature." 1 As originally adopted in the constitution of 1879 , the last sentence of $\S 6$ of article XI read as follows: "Cities and towns heretofore or hereafter organized, and all charters thereof framed or adopted by authority of this constitution, shall be subject to and controlled by general laws." It soon became the duty of the court, in a series of cases, to construe these words. In 1882, the court held, ${ }^{2}$ speaking through Justice Ross, that the Hartson act, an amendment to $\$ 4109$ of the Political Code, which provided for the election of county, city and county, and township officers, was a general law under $\S 6$ of article XI, and prevailed over the Consolidation Act, or charter of San Francisco. The court declared broadly that municipal charters were "subject to and controlled by all general laws" except those for the incorporation, organization, and classification of cities and towns. In 1887, the court held, ${ }^{3}$ speaking through Justice Thornton, that the Vrooman act was a general law, and "controlled," that is, in effect, repealed, the provisions of the San Francisco charter relating to street work.
\end{abstract}

In 1888, the court held, ${ }^{4}$ speaking through Chief Justice Searls, that an act of 1885 , known as the Whitney bill, which provided for police courts in all cities of a specified population,

1 People v. Hoge (1880), 55 Cal. 612.

2 Staude v. Election Commissioners (1882), 61 Cal. 313.

3 Thomason v. Ashworth (1887), 73 Cal. 73; 14 Pac. 615.

People v. Henshaw (1888), 76 Cal. 436; 18 Pac. 413. 
was a general law and repealed the provisions of the legislative charter of Oakland relating to police courts. And in 1890, the court held, ${ }^{5}$ that this same act, the Whitney bill, rendered invalid a provision of the subsequently adopted freeholders' charter of Oakland relating to police courts. In another case in the same year, the court held, ${ }^{8}$ speaking through Justice Works, that the act of 1889 for the opening and widening of streets was a general law and as such invalidated a provision on the same subject in the Los Angeles freeholders' charter of 1889.

None of these decisions passed without vigorous dissent. In the Staude Case, Justice Sharpstein, Justice McKinstry concurring with him, was of opinion that the Hartson act did not apply to San Francisco, because it did not purport to be anything more than an amendment of the Political Code and, as such, not a general law under $\$ 6$, and, furthermore, because general laws under the constitution did not apply to cities organized before the adoption of the new constitution. In Thomason v. Ashworth, Justice McKinstry, Justice Sharpstein concurring with him, wrote a dissenting opinion, holding, as he had done in a previous dissent, ${ }^{7}$ that the Vrooman act did not apply to San Francisco.

In People v. Henshaw, Justice McKinstry again dissented. In the case of $\mathrm{Ah}$ You and in that of Davies v. Los Angeles, Justice Fox wrote dissenting opinions. Chief Justice Beatty wrote a brief opinion in the latter case, concurring in the dissent of Justice Fox, and declaring that he considered the cases of Thomason v. Ashworth, People v. Henshaw, and Ex parte Ah You to have been "erroneously decided."

Notwithstanding the force of these dissents, the supreme court firmly settled the doctrine that, under the original reading of $\S \sigma$ of article XI, the legislature had power, by general laws, to supersede or take away, without the consent of the municipality, the powers conferred upon it either by a special legislative charter or by a constitutional freeholders' charter,

5 Ex parte Ah You (1890), 82 Cal. 339; 22 Pac. 929.

- Davies v. City of Los Angeles (1890), 86 Cal. 37; 24 Pac. 711.

7 Thomason v. Ruggles (1886), 69 Cal. 475; 11 Pac. 20. 
and also to prevent, by anticipation, freeholders' charters from regulating matters already covered by general laws. ${ }^{8}$

\section{The "Municipal Affairs" Amendment of 1896.}

The "manifest intention" of the constitutional provisions establishing a supposably home-rule regime of municipal government in California was thus in effect thwarted. The result is stated by Justice Angellotti:? "These decisions had demonstrated that the power given by the constitution to cities to frame their charters for their own government, for the purpose, as was said in People v. Hoge, 55 Cal. 612, of emancipating them from the authority and control formerly exercised over them by the legislature in municipal matters, was unavailing if such charters could at once be superseded by any general legislative enactment. Under these circumstances, the section of the constitution providing that all cities and towns and the charters thereof should be subject to and controlled by general laws was amended by the addition of the words 'except in municipal affairs." "10

The purpose of this " municipal affairs" amendment of 1896 is explained by Justice Garoutte in the following words ;1 "For the purpose of getting at the true significance of these words, there is no brighter light to be shed upon them than is disclosed by a consideration of the reasons which moved the legislature to propose the amendment and the people to adopt it. What was the evil to be remedied? What was the good to be gained by this amendment? The answer is common, everyday history. It was to prevent existing provisions of charters from

8 Over against this construction is the provision of $\S 8$ of article XI, that a freeholders' charter, after being adopted by the voters of the municipality and ratified by the two houses of legislature, "shall become the organic law of the city and supersede any existing charter, and all amendments thereof, and all laws inconsistent therewith." The original section had the word "special" before the word "laws." This reading was continued in the amendment of 1887; but the word "special" has been omitted in the amendments of 1892, 1902, 1906, and 1911.

9 Ex parte Braun (1903), 141 Cal. 204; 74 Pac. 780.

10 The amendment rcferred to was adopted in November, 1896, and the last clause of $\$ 6$ of article XI has since read: "and cities and towns heretofore or hereafter organized, and all charters thereof framed or adopted by authority of this constitution, except in municipal affairs, shall be subject to and controlled by general laws."

11 Fragley v. Phelan (1889), 126 Cal. 383; 58 Pac. 923. 
being frittered away by general laws, which would repeal those provisions by implication. It was to enable municipalities to conduct their own business and control their own affairs, to the fullest possible extent. in their own way. It was enacted upon the principle that the municipality itself knew better what it wanted and needed than did the State at large, and to give that municipality the exclusive privilege and right to enact direct legislation which would carry out and satisfy its wants and needs. These are a few of the reasons which gave occasion for this concise, but all-significant, amendment to $\S 6$ of article XI of the constitution of the State. This amendment, then, was intended to give municipalities the sole right to regulate, control and govern their internal conduct independent of general laws, and this internal regulation and control by municipalities form those 'municipal affairs' spoken of in the constitution."

There can be no doubt that the form of expression "except in municipal affairs," and the way it was injected into the constitutional provision, put the meaning of the clause in doubt, or rather, added a new source of ambiguity thereto. The clause was applied in three cases in the three years immediately following the adoption of the amendment. In the first ${ }^{12}$ and second ${ }^{13}$ of these cases the court held certain acts of the legislature not applicable to San Francisco, the matter being a municipal affair and provided for by the Consolidation Act; and in the third, ${ }^{14}$ the court upheld a general statute as against a charter, because the matter dealt with was one of state concern. But in no one of these cases was any question raised as to the interpretation of the constitutional provision.

In the fourth case, however, decided in $1899,{ }^{15}$ we find much space devoted to the interpretation of the amendment, and several divergent views expressed. The opinions, of which there were three, diverge on two points of construction: (1) the meaning of the words "municipal affairs," or the criterion by which to determine when an affair is of a municipal nature and when of state concern; and (2) the implication of the

12 Morton v. Broderick (1897), 118 Cal. 474; 50 Pac. 644.

13 Popper v. Broderick (1899), 123 Cal. 456; 56 Pac. 53.

14 People v. City of Oakland (1899), 123 Cal. 598; 56 Pac. 445.

15 Fragley v. Phelan (1899), 126 Cal. 383; 58 Pac. 923. 
phrase, "except in municipal affairs," that is to say, whether it implies a grant by the sovereign to all cities under constitutional freeholders' charters and to all cities under special legislative charters antedating the new constitution, of power to exercise control over "municipal affairs" without specification in the charter, or whether it only protected such cities from interference in the matters provided for in their charters. Of these three opinions, one was written by Justice Garoutte and concurred in by Justices Van Dyke and McFarland; the second was written by Justice Harrison and concurred in by Chief Justice Beatty and Justice Henshaw; and the third was written by Justice Temple. The view taken by Justice Harrison, on the second point mentioned, is the one that has been the guiding rule of the court in all subsequent decisions. His holding is, in a word that a city in order to obtain exemption from legislative control in a municipal affair, must have made distinct provision for such municipal affair in its charter. Justice Harrison uses the following language: "Under these considerations it must be held that the exception in the above clause in $\S 6$ of article XI, placed there by the amendment of 1896, applies only to such municipal affairs as are within the power of the particular municipality to perform, and that every city in the State is subject to and controlled by general laws relating to municipal affairs, unless, by virtue of some provision of the charter under which it exists and is acting, such municipal affairs may be engaged in and performed by it. The clause is to receive a distributive construction, and is to be read as if its language were: 'Any city or town heretofore or hereafter organized, and every charter thereof framed or adopted by authority of this constitution, except in its municipal affairs, shall be subject to and controlled by general laws." "He gives no reason for adopting this distributive construction, nor why "its" rather than "any" or "all" should be interpolated before the words "municipal affairs." We are further perplexed by the following sentence. We can not say exactly what it means, and under any view of its meaning, it is an argument more appropriate for the legislative hall or the popular forum than for the judicial bench. It is frequently quoted with approval, as if the doctrine which it seems to imply had averted a catastrophe. The sentence we refer to is: "If, by adopting a charter which failed to give to it power to act upon affairs which are properly 
municipal, a city could be freed from any legislative control in reference to those affairs, either by itself or by the legislature, that city would become a veritable Alsatia." This is like a similar cry in the wilderness uttered by Justice McFarland in two cases, applying this same section of the constitution. ${ }^{18}$

Justice Temple, in his opinion in the Fragley Case, took a different view of the import of the amendment, and repeated his interpretation in subsequent cases. His position is set forth in the following language used in a concurring opinion in a case decided in $1901::^{17}$ "If such power is not found in the charter, it is my opinion no general law can add that provision to the charter. I do not comprehend how it can be said that a statute which confers upon a city council additional powers over affairs of the city,-powers which have always been deemed municipal, and only concern the city as such,-which authorizes the city to incur indebtedness of four million dollars, and which makes

18 Ex parte Braun (1903), 141 Cal. 204; 74 Pac. 780; In re Pfahler (1906), 150 Cal. 71; 88 Pac. 270; 11 Ann. Cas 911. In the former case we have this lamentation:-

"I am reluctantly constrained to conclude that, by the amendment to the constitution in question, the people of the State, moved by a temporary impulse (not yet entirely abated) to carry the notion of what is called 'local self-government' to extremes have taken away from the State an important part of the peculiar attribute of sovereignty, the taxing power, and given it to all the municipalities, great and small, which are now organized, or which may be hereafter organized, under freeholders' charters. It is difficult to realize that the people of the State, through their legislators, have no longer the power to say that a license-tax - a tax upon the right to do business, a tax upon capacityis unjust, unequal, and oppressive, and should not be tolerated, anywhere within the State; but we think that such is now the law."

In the second we find this prophecy of evil: "The initiative in the Los Angeles charter embraces a large power of general legislation which usually belongs to the State. Already a municipality is independent of the State as to all legislation relating to municipal affairs; and we all know how difficult it is to determine how far legislation as to "municipal affairs.' runs into general legislation. Moreover, considering the generosity with which the people of the State have given away their powers to municipalities, there is no telling how much further they may go in that direction. If this disposition continues, the time may come when California will be not much more than a shadow of a name-used to designate the territory within which exist certain almost free cities and independent municipalities. Why should the people of the State, with their present love of municipal power, restrict the legislative power of a municipality to 'municipal affairs'? Why should not each municipality have its own substantive law in all ordinary matters of legislation, no matter what the law on any subject might be in other municipalities, or in other parts of the State? And the initiative would then cover substantially all the legislation in the State."

17 Fritz v. San Francisco (1901), 132 Cal. 373; 64 Pac. 566. 
necessary a large annual expenditure by the city forever thereafter, is not a municipal affair. If a general law having such effect is not prohibited by $\S 6$ of article XI of our constitution, then language has lost its force, and nothing has been accomplished by this long struggle and many amendments to the constitution for the purpose of preventing interference with municipal affairs."

\section{The Rule of Construction Adopted.}

The construction of Justice Harrison, however, is, as has been said, the settled one of the supreme court, and no countenance is given to the contention of Justice Temple. This construction may be found clearly expressed in the many well-considered and admirably stated opinions of Justice Angellotti. "The words used in the amendment are words of wide import, broad enough to include all powers appropriate for a municipality to possess and actually conferred upon it by the sovereign power." 18 "The provisions of a city charter in regard to a municipal affair are paramount to general laws of the State." 18 "It is unnecessary to cite authorities to the well-established proposition that under the 'municipal affairs' amendment . . . provisions in a freeholders' charter of a municipality as to municipal affairs are paramount to any law enacted by the state legislature, and that the legislature is without power to enact any law infringing thereon." ${ }^{20}$ We find in the brief of respondents' counsel, Messrs. Haines \& Haines, in a case decided in $1911,{ }^{21}$ the following very accurate statement of the rule: "We have examined all the authorities cited for appellant. We submit that not one of them aids the contention for the appellant. They go to the one established point, that where the charter speaks concerning the matter, which is in its nature a 'municipal affair the constitutional amendment of 1896 makes such provision paramount to any general law on the subject. But not one of these cases can be properly quoted for authority for the proposition that, upon subjects upon which the charter is silent, the general law does not control; nor does any

18 Ex parte Braun (1903), 141 Cal. 204; 74 Pac. 780.

19 In re Pfahler (1906), 158 Cal, 71; 88 Pac. 270; 11 Ann. Cas. 911.

20 Rothschild v. Bantel (1907), 152 Cal. 5; 91 Pac. 803; Sunset Telegraph \& Telephone Co. v. Pasadena (1911), 161 Cal. 265; 118 Pac. 796.

21 Clouse v. City of San Diego (1911), 159 Cal. 434; 114 Pac. 573. 
one of them suggest any support for the contention that upon subjects concerning which provision might be made in the charter, but concerning which no provision has been made in the charter, the general law does not control."

The determination by the court whether any given matter is or is not a municipal affair has not occasioned any serious trouble. Justices Garoutte, Harrison, and Temple, in their several opinions in the Fragley Case, took somewhat different views as to the import of the term and as to the criterion for deciding when an affair was municipal or was not municipal; but the solution of the question has never caused the court any real difficulty. Justice Angellotti has said :22 "There has been much discussion in our decisions as to what matters are embraced in this term, and it has been said that it is very difficult, if not impossible, to give a general definition clearly defining the term 'municipal affairs' and its scope." Accordingly, the court has wisely abstained from attempting to tie itself up with a definition, the concrete question being in each case whether the matter at issue was or was not within the scope of municipal functions. The court has carefully and judiciously discriminated between local and state affairs, and as a matter of fact in the larger number of litigated cases has held the "affair" in question to be within the purview of municipal activity. Not more than two cases, it is believed, are open to criticism or question, and these are probably sustainable on their facts. ${ }^{23}$

\section{Review of Cases Involving "Municipal Affairs."}

We proceed to make a brief review of the decisions involving the question whether an affair is municipal or not. First, we shall give the cases holding certain affairs to be municipal; and secondly, we shall give the cases holding certain affairs not to be municipal.

Regulating the mode and manner of passing city ordinances

${ }^{22}$ Sunset Telegraph \& Telephone Co. v. Pasadena (1911), 161 Cal. 265; 118 Pac. 796.

23 The two cases which, it is suggested, may be open to doubt, are Fritz v. San Francisco (1901), 132 Cal. 373; $64 \mathrm{Pac}$. 566, and Coffey v. Superior Court (1905), $147 \mathrm{Cal}$. 525; $82 \mathrm{Pac} .75$. The straining, if there be such, is in opposite directions in the two cases. In the Fritz Case the court found in the San Francisco charter "a complete and perfect scheme for the acquisition of permanent municipal improvements." Many pieces of the charter had to be patched together to get anything like a perfect scheme, but the result was, in the opinion of the court 
falls within the scope of charter provisions, as, for instance, requiring or not requiring the mayor's signature, ${ }^{24}$ or as providing for direct legislation by the people through the initiative. ${ }^{25}$ The opening, widening and vacating of streets of a municipality is a purely municipal matter, ${ }^{26}$ and it is assumed in all the decisions that the control of city streets is a local or municipal affair, although most municipalities have chosen to have the matter of street work governed by the Vrooman act. Secondary uses of streets, such as the maintenance therein of telegraph and telephone poles and wires, have been held to be municipal affairs. $^{27}$ Issuance of bonds for the acquisition and improvement of parks and boulevards, ${ }^{28}$ and for permanent municipal buildings and improvements, ${ }^{29}$ may be provided for by charter. It is within the functions of a city to levy and collect license taxes for purposes of revenue, if so authorized by the charter, even if the Code may declare that license taxes shall be levied only for purposes of regulation..$^{30}$ It is competent for a city to make exclusive provision for municipal elections, ${ }^{31}$ and for the removal of municipal officers, such as the chief of police. ${ }^{32}$ A municipal pension system will supersede a state law on the same subject. ${ }^{33}$ It is a municipal affair to provide for the prosecution of offenses which are made such by reason of charter provisions or city ordinances. ${ }^{34}$ Provision in a city charter

that such provisions in the charter had effectually superseded the general park and boulevard act of 1889 , with the consequence that the proceedings taken under that statute had to go by the board. In the Coffey Case the court held that the provisions of the Sacramento charter for the removal of city officers did not exclude the superior court from concurrent jurisdiction, because, apparently, the scheme in charter was incomplete. This case has been distinguished in Dinan v. Superior Court (1907), 6 Cal. App. 217; 91 Pac. 806.

24 Morton v. Broderick (1897), 118 Cal. 474; 50 Pac. 644.

25 In re Pfahler (1906), 150 Cal. 71; 88 Pac. 270; 11 Ann. Cas 911.

${ }^{26}$ Byrne v. Drain (1900), 127 Cal. 663; 60 Pac. 433.

${ }^{27}$ Sunset Telegraph and Telephone Co. v. Pasadena (1911), 161 Ca1. 265; 118 Pac 796.

${ }^{28}$ Fritz v. San Francisco (1901), 132 Cal. 373; 64 Pac. 566.

29 McHugh v. San Francisco (1901), 132 Cal. 381; 64 Pac. 570.

30 Ex parte Braun (1903), 141 Cal. 204; 74 Pac. 780; Ex parte Helm (1904), 143 Cal. 553; 77 Pac. 453; Ex parte Lemon (1904), 143 Cal. 558; 77 Pac. 455; 65 L. R. A. 964; In re Dieh1 (1908), 8 Cal. App. 51; 96 Pac. 98.

31 People v. Worswick (1904), 142 Cal. 71; 75 Pac. 663.

32 Dinan v. Superior Court (1907), 6 Cal. App. 217; 91 Pac. 806.

33 Burke v. Board of Trustees (1906), 4 Cal. App. 235; 87 Pac. 421.

${ }^{34}$ Fleming v. Hance (1908), $153 \mathrm{Cal}$. 162; 94 Pac. 620. 
regulating the pay of firemen and policemen will not be nullified by an act of the legislature. ${ }^{35}$ It has been held that "the supplying of water to outside territory, being necessarily a matter incidental to the main purpose of supplying water to its own inhabitants, is as much a municipal affair of Pasadena as is the main purpose, which is conceded to be such, and therefore the charter provisions relating thereto prevail over the general laws, if inconsistent therewith." 36

Two decisions, one holding that a charter board of health superseded a board of health under the Political Code, ${ }^{37}$ and the other holding that a superintendent of the almshouse appointed by the charter board of health could hold against the will of the Code board, ${ }^{38}$ must, probably, be taken for only the exact points of decision. The latter case was decided on the authority of the former. In the former case, Justices Temple, Van Dyke, McFarland, and Harrison wrote separate concurring opinions. Their language is sometimes very broad. For instance, Justice Harrison says: "The supervision and control of the sanitary condition of a city, and provision for the health of its inhabitants, are, as is shown in the opinion of Mr. Justice Temple, eminently a 'municipal affair'; and the establishment of a board of health which shall have the management and control of that 'affair' is an appropriate provision of a municipal charter." The language used in the opinions in this case, if not the points decided in both cases, come near to holding that police and sanitary powers conferred upon cities in $\S 11$ of article XI of the constitution may be converted into "municipal affairs" by being claimed in the charter.

On the other hand, the courts have declared certain matters to be beyond the power of municipal control, to be general, or state, affairs, and not municipal affairs. These "state" matters may perhaps be susceptible of classification into: (1) annexation of territory; (2) courts and control of crimes; (3) public school system; and (4) "county" affairs in a consolidated city and county. The question, in this connection, that has been

25 Popper v. Broderick (1899), 123 Cal. 456; 56 Pac. 53.

${ }^{36}$ South Pasadena v. Pasadena Iand \& Water Co. (1908), 152 Cal. 579; 93 Pac. 490.

37 People v. Williamson (1902), 135 Cal. 415; 67 Pac. 504.

${ }^{38}$ Weaver v. Reddy (1902), 135 Cal. 430; 67 Pac. 683. 
most frequently before the supreme court, is that of the annexation of outside territory to an incorporated city. The court, under whatever form this question has arisen, has held that the annexation of territory, like the original establishment of a municipality, was emphatically a matter which concerned the state, and accordingly beyond the province of a municipal charter. ${ }^{39}$

The court seems to be fairly fixed in its view that the judicial system and the jurisdiction over crimes are matters of state concern, and that any derogation therefrom in favor of municipalities must be shown by special constitutional exception. ${ }^{40}$

"The school system," says Justice Shaw, "is a matter of general concern, and not a municipal affair." 11 This doctrine had been anticipated by Justice Harrison, in one of his series of admirable opinions construing the school law, before the date of the adoption of the amendment of $1896 .{ }^{42}$ This is doubtless a sound general principle; but while our public schools constitute a state system, they are administered locally, and there are probably qualifications to be made to the generality of this rule. One qualification, at least, has been recognized. ${ }^{43}$ It is said: "The education of the youth is properly included within the functions of a municipal government . . . As schoolhouses are essential aids in the promotion of education, their erection is but incidental to the maintenance of the schools, and falls as completely within the functions of a municipal

39 People v. City of Oakland (1899), 123 Cal. 598; 56 Pac. 445; People v. Town of Ontario (1906), 148 Cal. 625; 84 Pac. 205; People v. City of Los Angeles (1908), 154 Cal. 220; 97 Pac. 311; People v. City of Long Beach (1909), $155 \mathrm{Cal} .604 ; 102 \mathrm{Pac}$. 664. In the last case, certain irregularities in the proceedings taken under the general statute of 1889 had rendered an election for the annexation of Terminal Island to the city of Long Beach invalid. A freeholders' charter for Long Beach adopted after such election purported to include Terminal Island within the boundaries of the city. The court held that such a charter provision was ineffective and void.

40 Jackson v. Baehr (1903), 138 Cal. 266; 71 Pac. 167; Robert v. Police Court (1905), 148 Cal. 131; 82 Pac. 838; Marysville v. Yuba County (1905), 1 Cal. App. 628; 82 Pac. 975; Farmer v. Behmer (1909), 9 Cal. App 773; 100 Pac. 902.

41 Hancock v. Board of Education (1903), 140 Cal. 554; 74 Pac. 44.

42 Kennedy v. Miller (1893), 97 Cal. 429; 32 Pac. 558.

43 Wetmore v. Oakland (1893), 99 Cal. 146; 33 Pac. 769; Iaw v. San Francisco (1904), 144 Cal. 384; 77 Pac. 1014. 
government as does the erection of a hospital for its indigent. poor, or buildings for its fire engines; and the schoolhouses when so erected are as fully municipal buildings as are its engine houses and hospital buildings."

It is well settled that, in a consolidated city and county, the "county" character of government is not extinguished, and hence it has been held, "4t that "county" affairs in such a consolidated city and county, like the payment of salaries of probation officers under the Juvenile Court Law of 1909, must be governed by state laws and not by the municipal charter.

In reference to the effect of the amendment of 1896 to $\S 6$ of article XI on pre-existing charter provisions, it has been held that where a charter provision was valid when adopted but was subsequently superseded by a general law, the charter provision was revived by the constitutional amendment; ${ }^{45}$ but, where the charter provision was invalid when passed because in conflict with a general law, no effect was given to the charter provision by the amendment. ${ }^{48}$

In closing this review of the decided cases, we would call attention to a significant case decided in $1911,{ }^{47}$ in which the court enforced a very important principle. In this case, the charter of San Diego referred to the general law for the procedure to be followed in issuing bonds for public improvements. After certain bonds were voted and issued for specified public improvements, the city authorities directed the board of public works to expend the proceeds of the bonds in accordance with provisions of the charter relating to the expenditure of the general funds of the city, instead of according to the general bonding act. The court held, that, where a charter had incorporated

44 Nicholl v. Koster (1910), 157 Cal. 416; 108 Pac. 302.

45 Byrne v. Drain (1900), $127 \mathrm{Cal} .663 ; 60$ Pac. 433. In this case, the freeholders' charter of Los Angeles was ratified by the legislature on January 31, 1889, and contained a provision for opening streets. There was no general law, and this charter provision was valid. On March 6,1889 , however, a general street opening act was passed, which superseded the charter provision. The court held that the amendment of 1896 revived the charter provision.

46 Banaz v. Smith (1901), 133 Cal. 102; 65 Pac. 309; German Savings \& Loan Society v. Ramish (1902), 138 Cal. 120; 69 Pac. 89; 70 Pac. 1067; Ex parte Sweetman (1907), 5 Cal. App. 577; 90 Pac. 1069; Postal Tele. graph-Cable Co. v. Los Angeles County (1911) 160 Cal. 129; 116 Pac. 566.

47 Clouse v. City of San Diego (1911), 159 Cal. 434; 114 Pac. 573. 
by reference a statute for bonding for public improvements, such statute furnished the measure of power of the city council with reference to the matters involved and must be followed out to the end.

\section{Suggested Amendment to the Constitution.}

The supreme court has held that the functions of government are of two kinds, state or general, and local or municipal. It has been decided that the phrase "except in municipal affairs" is permissive in its nature, that is to say, authorizes a city through its charter to bring within its functions every power that can rightfully be construed to be municipal, "all powers appropriate for a municipality to possess." 18 This implies that that city, whose charter-makers are shrewd enough, may go to the extreme limit and exhaust the entire reservoir of municipal affairs, leaving no control over such matters in the hands of the legislature. Such is now the endeavor of charter-makers.

The courts have interpreted $\S 11$ of article XI of the constitution to be a direct and positive grant to cities of power to pass and enforce within their limits all police and sanitary regulations that are not inconsistent with general laws. There is ever present in the minds of the lawyers of the State, especially of such as are concerned in the drafting of charters, the question whether a police or health regulation by being explicitly provided for in the charter may not be taken over into the category of "municipal affairs" and so placed beyond the possibility of being superseded by general laws. Cases which have been adverted to already seem to lend countenance to such a view. If such is not a fact, then no police or health measures can be municipal affairs, - - a result which seems absurd. That the assumption is a correct one, that police and health matters may be brought under the protection of $\S 6$, is shown by what seems to the writer the proper construction of $\S 11$ of article XI. This section would seem, considering all the provisions of article XI together, not to intend to confer upon cities power in municipal affairs, or only in municipal affairs, but to go farther and operate as a provisional derogation of the State's authority. Sections 6 and 11, especially, should probably be read together, in such wise that all matters, including police and sanitary

48 Angellotti, J., in Ex parte Braun (1903), 141 Cal. 204; 74 Pac. 780. 
measures, if they are to be construed to be municipal in their nature, would come under the protection of $\S 6$; while $\S 11$ amplifies this rule to such an extent as to authorize municipalities to exercise power in matters of health and police which may be of state concern, but over which the State has not assumed control. There are provisions of the constitution, it may be remarked, as, for instance, in $\S 8 \mathrm{I} / 2$ of Article XI, which allow cities to provide in their charters for the exercise of powers concededly of state concern.

It becomes incumbent, then, under present conditions, for charter-makers to see that their city is given full measure of power, to see that, so far as experience and foresight can show the way, they make their city ready for every contingency and emergency. The result must, of course, be a bulky and sometimes complicated charter, calling for frequent amendments in order to insert omitted functions. This is a situation that ought to be relieved, if it can be done in the interests of both local communities and of the State at large.

To the writer it seems obvious that great advantage would accrue and no dangers be threatened, if the constitution were so amended that the implication of the words " except in municipal affairs" as construed by the court were șhifted from a negative to a positive meaning. Our suggestion would be that the wording of the clause be so altered as to imply in and of itself a grant, to all cities organized under freeholders' charters, of a power to legislate in all municipal affairs. No city, it is to be observed, would then have more authority than any city can now have. But the work of the charter-maker would be immeasurably simplified, and, what is of more consequence, the charter itself would be shortened and simplified, would then in fact become what the "organic law" (Const., art. XI, § 8) of a city should be.

Under the proposed change, the problem of the charter-maker would be what the problem of the maker of a state constitution is, namely, to provide the machinery of government, the organs of legislation and administration, and to impose the necessary restrictions and limitations. The state constitution declares that "the legislative power of this State shall be vested" in such and such a body; and that "the supreme executive power of this State shall be vested" in such and such an officer. If a municipal charter could be predicated on a like principle, not 
only would the charter be simplified, and the objects now sought to be accomplished in a laborious way would be attained with ease, but a logical and harmonious system of municipal governments would be secured for the whole State. The controlling theory of the charter might be expressed in this wise: "Under and in accordance with the provisions of the constitution of the State of California, this City shall have complete powers of legislation and administration in all municipal affairs, to be exercised in the manner and under the conditions provided in this charter." Under such a system, the court's problem would, likewise, be simplified. The court now has to decide (1) whether the matter at issue is a municipal affair, and (2) whether the matter is explicitly, or perhaps impiedly, ${ }^{49} \mathrm{se}-$ cured by charter provision. The second inquiry would disappear, but the first would of course always remain, and it would always be within the jurisdiction of the court to determine whether the power claimed was one of municipal concern or one of state concern. The distinction between "state affairs" and "municipal affairs" is a permanent one. A municipality will never be able to invade the domain of state affairs, except by express authorization, as now in certain particulars under $\S 8 \mathrm{r} / 2$ of article XI of the constitution.

Most boards of freeholders, under the proposed regime, would, as at present, incorporate by reference the Vrooman act, the general bonding acts, and other general laws which are satisfactory in themselves and have received judicial construction. Many boards of freeholders would adopt the general election laws, general franchise law, and such other laws as appealed to the general public mind of the community. A stimulus would be furnished to the legislature to bring their general laws affecting counties and municipalities to a higher standard.

Either home-rule in municipal affairs is right, or home-rule in municipal affairs is a mistake. If a mistake, we should go back and restore to the State full authority irrespective of charter

49 One who is engaged in drafting a municipal charter is rather wary of leaving municipal powers to implication. The decision in South Pasadena v. Pasadena Land \& Water Co. (1908), 152 Cal. 579, 93 Pac. 490, was a welcome intimation that the court would recognize the existence of incidental powers; but a board of freeholders would hesitate to bank very largely on that decision. 
provision. If right, we ought to make home-rule as simple, natural and effective as possible. We have refrained from formulating an amendment, believing that it could be better worked out by a number of minds in consultation; but whatever the wording of the amendment proposed, it will not, we insist, enlarge the possible scope of power now residing in the municipalities of the State. For, as has been said, it is now open, even under the conservative construction of the supreme court, for any, and every, city in the commonwealth, to make up a complete catalogue of all imaginable municipal affairs, and leave nothing to be superseded by general laws.

WILLIAM CAREY JONES. 